体育学研究第 50 巻記念特集：体育方法

\title{
体育方法専門分科会の活動を顧みる
}

永嶋 正俊

\section{Review of research activities of division on sports coaching methods}

\author{
Masatoshi Nagashima
}

\section{Key words : practical study, various sports}

(Japan J. Phys. Educ. Hlth. Sport Sci. 50: 91-104, January, 2005)

キーワード：実践的研究，スポーツ種目

\section{はじめに}

（社）日本体育学会編集委員会の『体育学研究』 創刊 50 周年記念特集企画の原稿依頼に沿って, 体育方法専門分科会の来し方について報告する. 本分科会の創立から今日まで携わって来られた他 の諸学见もおられるので, 果たして, その任に值 する内容となるか些か心もとないが掉しいただ きたい。

\section{I 創立とその経緯}

ここでは，まず本分科会を創設し，初代世話人 代表になられた笠井恵雄先生の回顧をひもとくこ ととする。

（1）日本体育学会の発足当初の発表形態が 1955 年の第 6 回学会大会から, 発表部門制へと変更さ れ，〈指導に関する部門＞もその一つとして設け られた。そのときから，指導に関する論文の数は 発表部門の中で最も多く約 60 題だった. 当時の 論文の内容は科学的というよりも, 主観的なもの
も少なくなかった。

（2）1966年の春に当時の加藤橘夫理事長と水野 忠文常務理事との協議においてく指導に関する部 門 >の専門分科会を創ることを提唱し，両氏の賛 同を得た。そこで, 同年の東海大学での学会大会 の総会においてく指導に関する研究領域 >をより 発展させるために「体育方法専門分科会」の創設 を提案し，賛成と承認を得て，笠井恵雄世話人代 表のもと東京教育大学体育学部（当時）に事務局 を置いて発足した。

（3） 1968 年 9 月の第 19 回大会総会で，体育方 法専門分科会の設立が認められ，1969年からこ れまで称してきたく指導に関する研究領域〉に代 わって, “体育方法”という研究領域で活動する ことになった。分科会を設立した当時には“体育 方法”という概念の検討を深く行うことなく, そ の頃の発表題目を総括して選んだ（笠井, 1977).

（今日なお “体育方法”の概念が多面性・多様 性をもってとらえられがちなのは，この分科会創 立時の事情に起因しているのかも知れない.）

（4）発足当初から学会大会の発表部門にあっ たく指導に関する研究領域 >の内容を受けて諸研 究が発表, 報告された。そこには大きく分けて, 
二つの研究分野が含まれていた。一つは運動技術 そのものの分析的研究や各種の運動の習熟過程の 研究であり, 他は各種運動種目の指導や体育学習 に関する研究であった。この両面の研究は前者が 自然科学的な研究であるのに比して, 後者は主に 教育学的方法を中心とする人文科学的研究であっ て, 両者は異なるものであるが, 関係の非常に濃 い間柄にある。一般的にいえば，前者は素材とし ての運動自体の研究であり, 後者は運動を利用し ての教育として，基礎科学と忍用科学という関係 にあって，前者は後者を助け，指導に貢献すると ころが大であると解釈されたようだ(笠井, 1997).

（5）日本体育学会の中で，〈指導に関する研究 分野〉が学会大会の研究発表者のために置かれて, 体育やスポーツの指導に関する各種の研究がここ で発表されてきた.分科会となった理由としては， 次のようなことが挙げられる.

(1)他の研究分野が専門分科会をもち，組織的に 研究を始めたのに，〈指導に関する研究分野〉だ けは分科会が設けられていなかった。研究発表の 題目数は他の分野に比較して多く, その研究内容 や対象も体育実践とのかかわりが強いため, 複雑 で，広く，研究するのには条件付けなどが極めて 困難な問題があったりして, 研究方法が不備で弱 点をもつものが目につくことも言われていた。 (2) このようなことと，この分野が体育・スポーツの 中で重要な研究領域であることを考えて，遅れば せながら専門分科会をつくらねばと考えた。（3)ま た，従来のこの分野の研究発表の傾向のうち，各 種の運動技術の科学的研究, 合理的な指導法, 体 育学習の指導法がとくに目立っていたため，これ らの3つを，主な内容として一層研究を深めよう と考えた（笠井，1975）。

（6）分科会の将来的なねらいとしては，〈運動 技術ないし運動方法学の研究〉と〈体育の学習指 導の研究〉は設立趣旨からいっても継続していく ことが望ましい。また, 最近の体育科教育学（教 授学）研究の強い機運を盛り上げて, 分科会を二 つに分けることが必要になったと思っている．何 れにしても，初期の設立動機であった研究の質を 高めることについては，分科会として責任をもっ
て一層進めていく必要を感じているが，会員の構 成からいって, 一方は運動学的研究が多く, 自然 科学的研究法を用いるのに対し，他は教科の目 的·目標論, 学習者論, 課程論, 教授・学習論, 評価論など人文・社会科学的研究法を用いるとい うことである．どうしても研究する会員が分離す る傾向にあるのは止むを得ない発展の方向ではな いだろうか（笠井，1977）。

以上のことから，次のことが明らかになった。

（1）本分科会は1968年の第 19 回学会大会総会 で設立が承認された。

（2）日本体育学会発足当初からあったく指導に 関する研究領域>に代わって “体育方法専門分科 会”を創設した。

（3）体育方法専門分科会を設立した当時には, “体育方法”という概念の検討を深くおこなうこ となく，その頃の発表題目を総括してこの名称を 選んだ.

（4）「専門分科会」としては，当時の<指導に 関する研究 $>$ の内容を受けて研究を進めることと した。 そこには大別して二つの研究分野があり， 一つは運動技術の分析的研究や各種運動技術の習 熟過程の研究で, 他は各種運動種目の指導や体育 学習指導に関する研究であった。

（5）本分科会の今後の方向として，＜運動技術 ないし運動方法学の研究 $>$ と<体育の学習指導の 研究>は分科会設立の趣旨から継続していくこと が望ましいが, 体育科教育学 (教授学) 研究の強 い機運を考えると分科会を二つに分けることが必 要になった。（因みに，体育科教育学専門分科会 は体育方法専門分科会創設から 10 年後に分離独 立した。）

\section{II 体育学会大会における『一般研究発表』 演題数の推移}

表 1 は日本体育学会が公にしている「日本体育 学会 50 年のあゆみ」の抜粋である。これを通覧 すると，次のようなことが読み取れる。

（1）専門分科会別の発表演題数を見てみると, 第 21 回大会の「体育方法」は 183 で全発表演題 
表 1 学会大会の開催場所・参加者数等

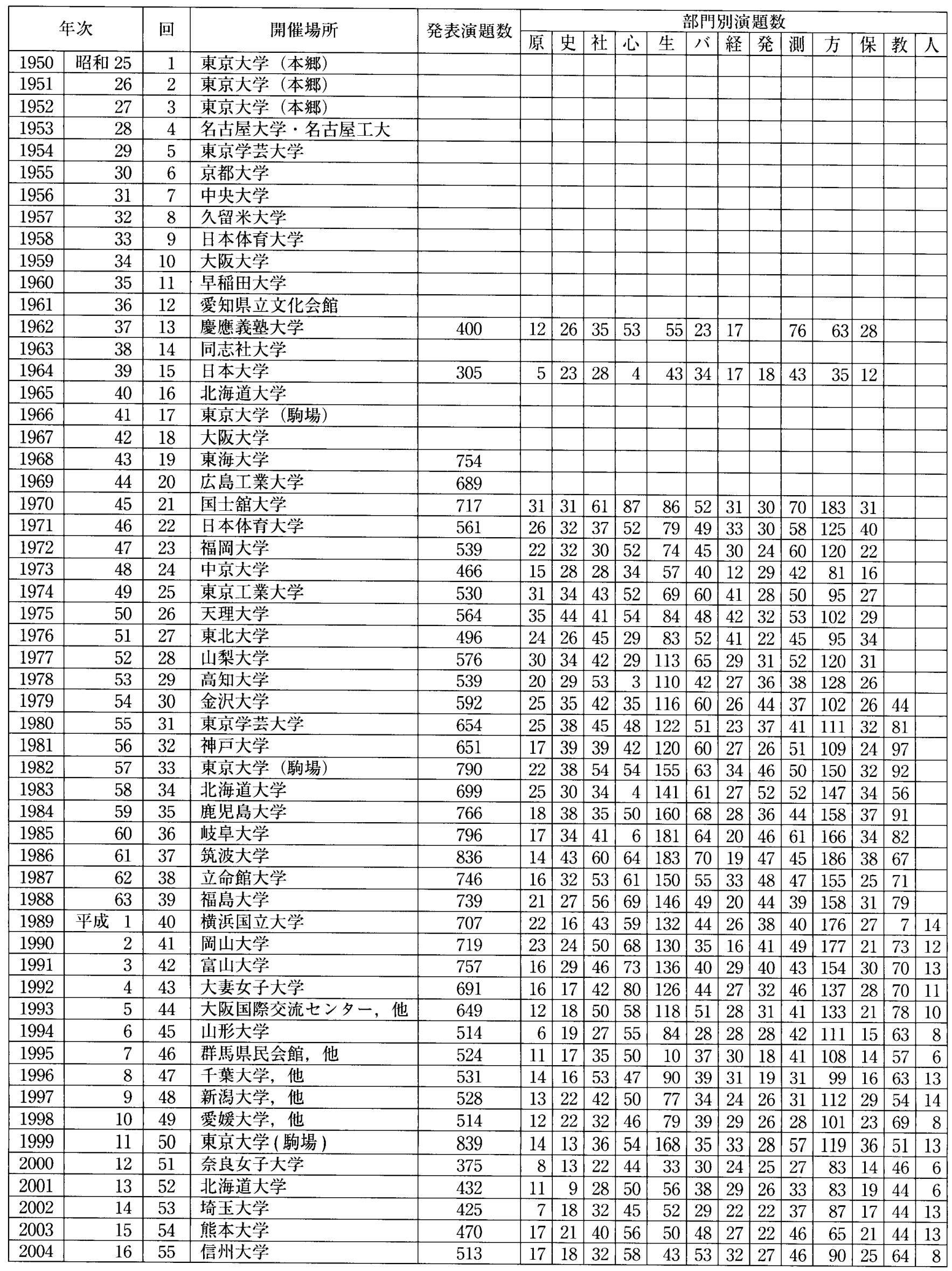


数の $25.5 \%$ 占める，顕著な演題数であった. 「体育方法専門分科会」が新設されたことを受け て，従来の<指導に関する研究分野 $>$ 発表に加 えて多くの会員の本分科会における研究発表がな されたものと思われる。

（2）第 21 回大会以降，第 29 回大会まで発表演 題数は他の専門分科会のそれを上回っている，体 育学会の会員の多くは大学教員として体育の授 業，体育・スポーツの実践指導に携わっているこ とを思慮すれば，体育・スポーツの効果的な指導 を探るティーチング，トレーニング，コーチング の研究とその発表が多く見られるのは当然の成り 行きだったと思われる。

（3）第30回大会から第 36 回大会まで（第 34 回 を除く）の専門分科会別の発表演題数は運動生理 学専門分科会が体育方法専門分科会よりも多い. このことは，体育・スポーツの基礎科学としての 運動生理学の研究が盛んになったことと, 本分科 会から分離する形で “体育科教育学専門分科会” が新設されたことによる影響ではないかと考えら れる。

本分科会の発足当初から，従来の<指導に関す る研究分野>には，大別して『運動技術ないし運 動方法学の研究』と『体育の学習指導の研究』が あった，研究のさらなる専門性を求めて”体育科 教育学専門分科会“が 10 年を経て分離, 新設さ れたことは当然の成り行きであったと思慮でき る.

（4）第 37 回大会以降第 55 回大会までの 19 回の うち, 第 50 回記念大会で運動生理学専門分科会 の演題数（168）が体育方法学専門分科会の演題 数（119）を上回った以外，18回の学会大会での 一般研究発表演題数は本分科会が常に最多であっ た。体育科教育学専門分科会の分離，新設から 7 年を経て，体育・スポーツの実践指導に携ってい る多くの本分科会所属会員が，運動技術・スポー ツ技術の方法学的研究に取り組み，それが多くの 研究の触発につながり, 発表となったと思慮でき る.

以上のように,体育・スポーツの方法学的研究, 実践科学的研究が着実に根を下ろし，継続的に多
くの研究・発表がなされてきていると見ることが できる．これらの研究結果を実際の体育・スポー ツの指導・コーチングに生かし，更なる実践的指 導の成果，コーチングの成果を挙げることが期待 される。

\section{III 日本体育学会第 21 回大会と第 55 回 大会の『一般研究発表』の比較}

第 21 回大会と第 55 回大会の一般研究発表の傾 向を，本分科会のコード表をもとに，発表テーマ の内容を勘案して新たに項目を加えた分類表の頻 数から概観してみる (表 2 参照)。なお，分類項 目ごとの頻数は発表テーマから算出した，体育方 法総論，体育方法論，運動方法の「網」の何れの 「目」に合う研究内容で，「種目」は何であるか等 を個々の発表ごとに算出した，例えば，「棒高跳 びの局面構造に関する実践的研究」のテーマの場 合，陸上競技，技術分析（動作分析），実践研究 のそれぞれの項目に一つづつ加算して算出した。 また，「平泳ぎ下肢動作の三次元動作分析」のテ 一マの場合は水泳，技術分析の項にそれぞれ加算 し，「庭球の指導に関する研究」のテーマの場合 は球技，指導の項にそれぞれ加算した。

以上のような処理のしかたで項目別に頻数を算 出した結果，表 2 に示すように項目別頻数は第 21

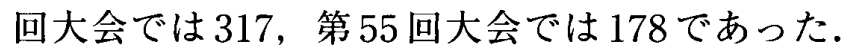
第 21 回大会は第 55 回大会の 2 倍の演題数であっ た。

第 21 回大会では，従来より<指導に関する分 野＞として広範囲にわたり，多くの発表がなされ ていたが，新たに「体育方法専門分科会」として 発表分野が特定されたこともあって，さらに多く の発表数になったものと思慮できる.

第 55 回大会の発表数は第 45 回大会以降の学会 大会の『一般研究発表』総数の漸減傾向を受けて, 本分科会も減少傾向を示している結果とみること ができよう。（項目毎の比較をするのにそれぞれ 100 分率を算出して比較検討した。）

体育方法総論では，第 21 回大会が $2.2 \%$ ，第 55 回大会が $0.5 \%$ で運動特性論，指導方法論などの 
表 2 体育方法専門分科会 コード表をもとにした項目ごとの発表頻度

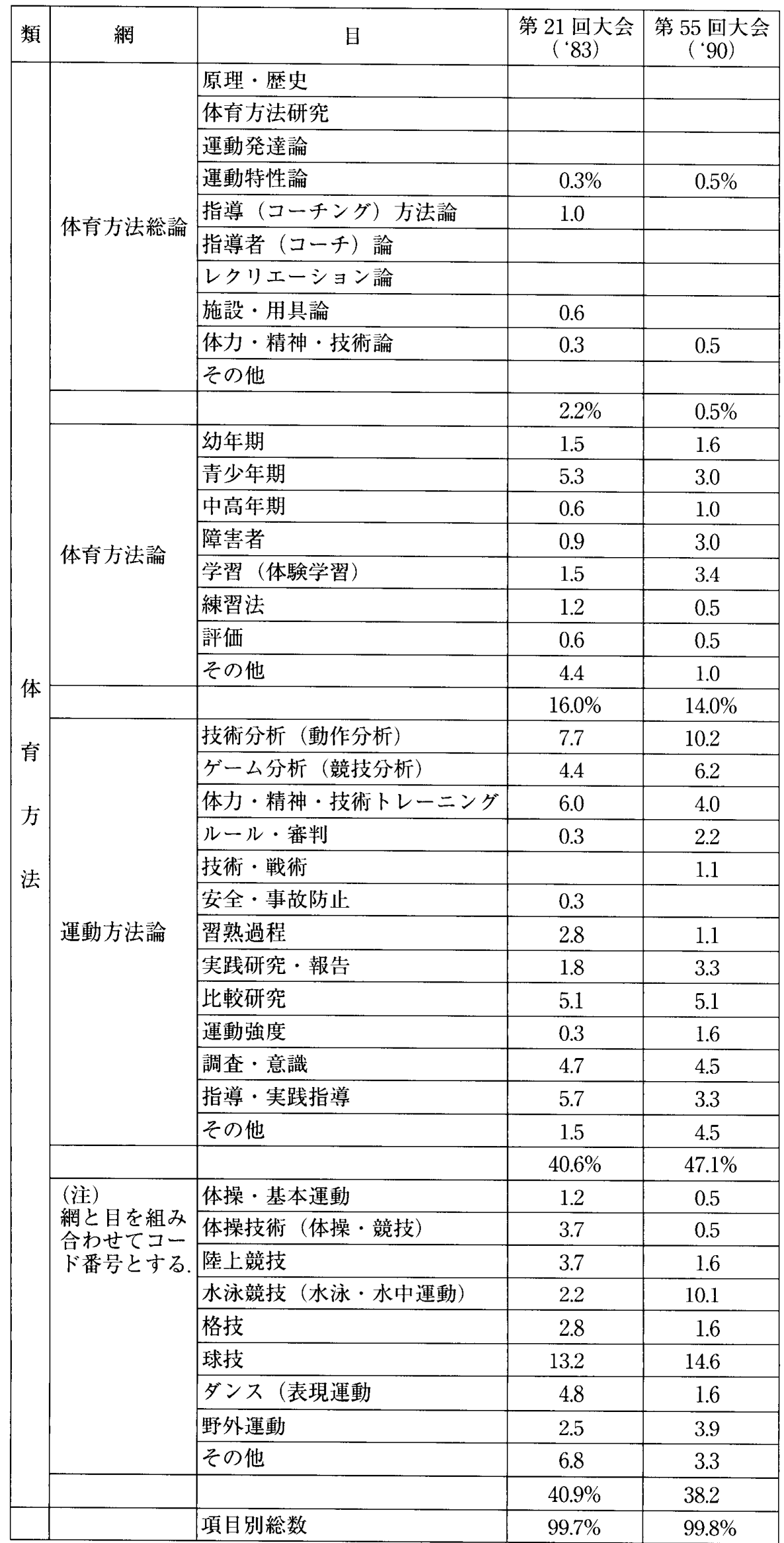


基礎的な研究は非常に少ない。体育方法論では, 第 21 回大会で $16.0 \%$ ，第 55 回大会で $14.0 \%$ あ り大きな差は見られないが，第 21 大会では中 学・高校生を対象にした授業関連のテーマが多 く，第 55 回大会では障害者に対する研究発表の 増加が見られた。

運動方法論では，第 21 回大会で $40.6 \%$ ，第 55 回大会で $47.1 \%$ あり，第 55 回大会の方が多か った．特に，技術分析，ゲーム分析に関する研究 の増加が著しく，ルール・審判の発表も増加して いる．第 21 大会では習熟過程，指導・指導実践， 体力・精神・技術トレーニング等が第 55 回大会 より多かった。

これらの結果は体育・スポーツ研究の現代的な 流れの中で, 体育・スポーツ方法学的研究の傾向 と見ることができる。これは，体育・スポーツ界 が求めている実践的な成果に結びつく実践科学的 な体育・スポーツ方法学の研究が多くなってきた 傾向とも換言でき, 今後も継続されていくものと 思慮できる。

運動・スポーツ種目から見てみると，第21回 大会で $40.9 \%$ ，第 55 大会で $38.2 \%$ 大゙大きな差異 は見られない，種目の括り方にもよると思われる が，球技が第 21 回大会で $13.2 \%$ ，第 55 回大会で $14.6 \%$ 著しく多いのは，球技に関わる研究者 (コーチ）が多いことを意味しているのであろう か. 第 21 回大会よりも第 55 回大会で多くなった 種目は水泳競技（水泳・水中運動）であり，顕著 に増加している $(2.0 \% \rightarrow 10.1 \%)$ ．逆に第 21 回 大会よりも第 55 回大会で減少している種目とし ては体操競技（3.7\% $\rightarrow 0.5 \%)$ ，陸上競技（3.7\% $\rightarrow 1.6 \%)$ ，ダンス $(4.8 \% \rightarrow 1.6 \%)$ などが際立っ ている.

研究対象としての種目別の増減は, 個々の種目 の普及度や国際大会的なオリンピックや世界選手 権大会の成績等も要因として考えられる。また， 別の要因として種目単位の研究組織（学会や研究 大会）の活動の有無が本分科会の発表数に影響し ているのではないかということも考えられる．種 目別発表数の増減を一面的に見ることは，体育 · スポーツ界の研究の実態を見誤ることにもなりか
ねないので，慎重な考察が必要である．またここ れのみならず体育方法専門分科会の『一般研究発 表』のテーマ，内容についての検討にあたっても 同様であることを付言しておきたい.

\section{IV 学会大会におけるシンポジウムの推移}

本分科会のシンポジウムは第 22 回大会から第 55 回大会まで，本分科会独自か他の分科会と合 同して開催してきている。（第26回大会は『課題 研究』に「体育方法」として参加し，第 50 回記 念大会ではスポーツ方法学会として，共催シンポ ジウム 8セクションに参加している.)

以下に学会大会ごとのシンポジウムのテーマを 略記してみる。

第 22 回大会

〔A〕サッカー技術の発達過程について

(1)戦前の日本におけるサッカー技術の発達

(2)戦後の日本におけるサッカー技術の発達

(3)外国におけるサッカー技術の発達

[B] 効果的な体育実践の指導法

(1)体力を中心として

(2)技能を中心として

(3)人間性を中心として

第 23 回大会

〔A〕わが国におけるスポーツ技術の発達過程

(1)ラグビー

(2)体操競技

(3)戦後の一般スキー

〔B〕体育科教育学の基本構想について

(1)体育科教育学と基本科学

(2)学校教育における教科構造の中の体育科の 位置

(3)体育科教育の学習内容について

(4)教員養成大学・学部に扔ける教職・教科に

関する専門科目及び体育科教育について 第 24 回大会

〔合同〕運動技術の習熟過程について 内野手の投球動作の成熟過程

〔合同〕小学校正課体育における適正な運動量 はどのくらいか 
第 25 回大会

球技におけるゲームの分析法一記録の仕方と整 理法一

(1)バスケットボール

(2)バレーボール

(3)ハンドボール

(4)野球について

第 26 回大会

〔課題研究〕体育学研究の成果と課題（体育方 法)

第27回大会

スポーツ技術の特性とそのコーチ

(1)陸上競技

(2)剣道

(3)サッカー

第 28 回大会

スポーツ技術の特性とそのコーチ

(1)陸上競技・長距離

(2)卓球

(3)柔道・クラブ強化のための

第 29 回大会

〔A〕社会体育における指導上の諸問題

(1)国立競技場におけるスポーツ教室

(2)少年スポーツについて

(3)中・高齢者の健康マラソン

(4) 家庭婦人の「健康 ・体力づくり」トレーニ ングについて

〔B〕体育の「授業研究」の現代的課題と今後 の研究のあり方

(1)授業理論の先行研究について

(2)体育の「授業研究」における現代的・方法 論的課題

(3)体育の授業研究の今後のあり方

第 30 回大会

体操と国民スポーツ

(1)体操の概念

(2)国民スポーツとしての体操

(3)古い体操・新しい体操

(4)欧州の体操とその傾向

第 31 回大会

ダンスと国民スポーツ
(1)フォークダンス（民踊）と国民スポーツ

(2)芸術ダンス（舞踊）と国民スポーツ

(3)学校ダンス（教育ダンス）と国民スポーツ 第 32 回大会

スキーと国民スポーツ

(1)スキー技術について

(2)学校スキーと国民スポーツ

(3)歩くスキー

第 33 回大会

スポーツ選手の男女差とコーチについて

(1)生理学からみた男女差

(2)長距離走のコーチと男女差

(3)バレーボールのコーチと男女差

第 34 回大会

スポーツ選手の男女差とコーチについて

(1)バスケットボールのコーチと男女差

(2)テニスのコーチングと男女差

(3)体操競技の男女差とコーチ

第 35 回大会

スポーツ選手の男女差とコーチングについて

(1)体力における女子の特性

(2)競泳競技のコーチと男女差

(3)陸上競技コーチングの男女差の諸問題 第 36 回大会

大学における体育・スポーツと指導者の養成に ついて

(1)改めて問われている大学体育の意義 一そ の理念論と効果論

(2)大学体育・スポーツと指導者の養成 一就 職難の時代に寄せて

(3)大学体育・スポーツと指導者の養成

(4)大学スポーツと指導者の養成について 第 37 回大会

大学における競技スポーツのあり方と指導

(1)大学の競技スポーツをトップクラスにする ための問題点

(2)大学の競技スポーツと指導者

(3)大学における競技スポーツの日米比較 第 38 回大会

大学における一般体育・スポーツの指導一指導 の科学化を含めて一 
(1)体育及び大学体育の新構想 $-21 \mathrm{C}$ に向け $\tau-$

(2)「大学」の特性を生かした体育指導

(3)大学における一般体育・スポーツの指導 (バレーボール)

(4)大学一般体育におけるテニスの指導につい $\tau$

第 39 回大会

「生涯スポーツ」の在り方を探る

(1)大学を生涯スポーツの場に

(2)生涯スポーツと大学体育

(3)高齢者の体力の現状とスポーツの貢献 第 40 回大会

必修に値する大学体育とは何か

(1)必修に值する大学体育とは

(2)大学一般体育（保健を含む）に関する発想 の転換

(3)必修に值する大学体育とは

第 41 回大会

生涯体育・スポーツにおける大学体育の在り方

(1)体育そのものの基本的な在り方から

(2)特色ある大学教育の実践例から

(3)アメリカの大学体育から

第 42 回大会

大学体育の方法を探る

(1)目的・目標を考える立場から

(2)自己評価の立場から

(3)カリキュラム・授業・成績評価の立場から 第 43 回大会

大学体育と新カリキュラム

(1)慶応義塾大学の場合

(2)設置基準の大綱化と体育の改善

(3)大学体育における「非専門科目」としての 体育の教育

第 44 回大会

コーチングを考える一その 1 一个世界に勝つた めに」

(1)サッカー日本代表チームのコーチング

(2)現役選手の立場から

(3)コーチと競技者としての両面から

第 45 回大会
コーチングを考えるーその 2 一世界に勝つた めに」

(1)金メダルまでの経緯（スキー）

(2)合理的なトレーニングと人間的交流がトッ プを支える（スケート）

(3)自転車はF1レーシングマシンになれるか （テニス）

第 46 回大会

〔A〕コーチングを考えるーその 3 -「世界に勝 つために」

(1)日本のコーチングに望まれるものーアメリ カ留学を通してー (バレーボール)

(2)日本人選手を指導して（飛び込み）

(3)日米バスケットボールの比較と違い

〔B〕体育方法専門分科会の発展的な在り方を考 える

(1)体育方法専門分科会の発展的な在り方

(2)アメリカに見られる体育・スポーツ学の体 系と諸独立学会の置き方

(3)ドイツにおけるスポーツ科学の体系論 第 47 回大会

コーチングを考える一その 4 一「世界に勝つた めに」

(1)アトランタオリンピック出場までの強化 (サッカー)

(2)アトランタオリンピック出場を果たして (バスケットボール)

(3)ワールドカップ'95チーム第4位からの出 発（シンクロナイズドスイミング）

第 48 会大会

コーチングを考える一その5一「世界に勝つた めに」

(1)「体験や勘」を超えるコーチングへ（スケ 一ト)

(1)ニッカネンを超える鳥人計画の 10 年（ス キー・ジャンプ)

(2)体力面の強化およびコーチ陣との接点（ス キー・ノルディック)

第 49 回大会

長野パラリンピックを考える一その成果と課題 をめぐって一 
(1)国際パラリンピックの全体像

(2)長野パラリンピックを終えて

(3)長野パラリンピックへの道のり

第 50 回大会〔体育学会 50 回記念大会〕

スポーツ方法学会として諸学会との共催シンポ ジウム 8 セクションに参加

第 51 回大会

〔合同〕スポーツ科学の 21 世紀への提言一シド

ニーオリンピックに学ぶー

アトランタからシドニーへ, そしてアテネに向 けて (体操競技) 一日本男子体操, 世界への再 挑戦一

第 52 回大会

競技力向上を目指す女性スポーツのコーチング

(1)女子柔道選手を対象とした場合

(2)ソフトボール競技のシドニー五輪までの選

手強化と今後に向けて

(3)シンクロナイズドスイミングの競技力向上 を目指す女子選手のコーチング

第 53 回大会

21 世紀の日本のサッカー・世界のサッカーー 2002FIFA ワールドカップを終えて一

(1) 日本サッカーの技術レベルの現状・課題

(2)世界のサッカーの現況

(3)日本のスポーツ界におけるサッカー

〔合同〕体育・スポーツ指導者の役割

体育・スポーツの文化特性に係る水泳指導法 の転機

第 54 回大会

〔A〕日本水泳 アジアからアテネオリンピッ ク〜世界の頂点へ〜

(1)強化サポートスタッフの立場から

(2)指導者の立場加

(3)これまでのアドバイスを振り返って

(4)これまでの強化を振り返って

[B]熊本が生んだマラソン王「金栗四三」を語 る

(1)地元で一緒に活動したジャーナリストの立 場から

(2)地元で一緒に活動した市民マラソンランナ 一の立場から
(3)オリンピック・マラソン選手の立場から

(4)オリンピック・マラソン選手の立場から 第 55 回大会

〔A〕日本水泳 アジアからアテネオリンピッ ク〜世界の頂点〜（II）-「チーム北島」は アテネオリンピックでどう戦ったかー

(1)演者 5 名による対話, 質疑応答形式

〔B]実学的な「泳ぎ」の指導法を問う一日本泳 法と近代泳法の視点から-

(1)演者3名による対話, 質疑応答形式

以上の本分科会のシンポジウムを概観すると, つぎのようなことが読み取れる。

（1）全体を通して見たときに，大きな流れとし ては，常に体育方法としての運動技術・スポーツ 技術を据えた実践科学的な視野に立ってテーマが 設定され，報告・討論・討議がなされてきた。

（2）そのときどきの体育・スポーツ界に関わる 教育改革（主として大学体育の改変）の流れやス ポーツのビッグイベント（オリンピックやワール ドカップ）に合わせたテーマ設定も目につく.

（3）生涯学習（生涯スポーツ）と大学の一般教 養科目の必修科目として位置づけられていた“一 般体育”との関わりやスポーツ種目ごとの生涯ス ポーツとの関わりを探るテーマも見られる．加え て, 体育・スポーツ活動を支える基礎科学の研究 成果（生理的・体力的等）を踏まえてのスポーツ 選手の男女差とコーチングについてのテーマ設定 も見られる。

(4) シンポジウムのテーマによってはシンポジ ス卜を球技種目・個人種目・対人種目・冬季種目 等の中だけから数人を選び, 種目特性の指導やコ ーチングの相違点や共通点を探ることをめざした り, 球技種目 - 個人種目・対人種目・冬季種目等 からそれぞれ選んで種目特性による技術構造の相 違点や類似点等から，それぞれの指導・コーチン グの相違点などを探ることをめざしている.

（5）競技種目ごとのコーチングを探るのに，コ 一千の立場, 選手の立場, 研究者の立場等からの シンポジストによる種目特性に応じた発表・報告 から，より有効なコーチングをめざしたり，我が 
国と外国のコーチングの実際の比較からよりよい コーチングを探ることをめざしたりしてきてい る.

さらに，次のような読み取りもできよう。

(1) 第 22 回大会から第 28 回大会では,「スポー ツ技術に関する」シンポジウムと見ることができ る. 第 22 回・ 23 回大会では「スポーツ技術の発 達過程」と題して, サッカー, ラグビー, 体操競 技，一般スキーについて討議されている．第 24 回大会では合同シンポジウムで，「運動技術の習 熟過程」について討議している. 第 25 回大会で は，「球技のゲーム分析法一記録のしかたと整理 法一」と題して, バスケットボール, バレーボー ル, ハンドボール, 野球について討議されている. 第 27 回・28回大会では「スポーツ技術の特性と そのコーチ」と題して，陸上競技，剣道，サッカ 一，陸上競技 (長距離), 卓球, 柔道について討 議している。これらの「スポーツ技術」に関する テーマは本分科会が創立されて，分科会としてと くに扱う研究分野，その研究方法等についてひと つの方向性をシンポジウムを通じて分科会所属会 員に示し続けてきた“あらわれ”と思慮できる。

(2) 第 30 回大会から第 32 回大会までの 3 回は 「体操と国民スポーツ」,「ダンスと国民スポーツ」, 「スキーと国民スポーツ」と題して行っている. 現在では「国民スポーツ」という用語はあまり用 いられなくなってきているように思われるが，各 種スポーツが日常生活の中にどのように位置づけ られ，実際に行われるようになることの必要性に 触れ，スポーツ実践活動の具体的例示について， 高校や大学の正課体育・クラブ活動の関わりを中 心に討議されている。レジャースキーの普及に合 わせて，スキーの技術，学校スキー，歩くスキー が扱われているのはスキーブームに即したテーマ であったと思慮できる。生涯学習・生涯スポーツ についてのシンポジウムでもあったと換言できよ う.

（3）第 33 回大会から第 35 回大会までは「スポ ーツ選手の男女差とコーチング」のテーマで行わ れている．体育・スポーツ活動に関わる諸基礎科 学の研究が進み, 生理学的な性差や体力的な性差
等が明らかになるにつれ，スポーツ技術の指導・ コーチングについての男女差が課題となるのは当 然のなりゆきであった。シンポジウムでは生理学 からみた男女差，体力における女子の特性などを 踏まえて，種目特性に応じたコーチングの男女差 について討議している。種目としては陸上競技, 体操競技, 競泳競技，バレーボール，バスケット ボール，テニスが取り上げられている。当時，男 子・女子が共に行っていた主な種目のコーチング の実際を踏まえて共通点や相違を示し，課題を明 らかにして，その課題解決策を討議するシンポジ ウムであった。男女差を考慮したコーチングの実 践研究はその後も継続され，とくに女子の技術向 上に大いに寄与したことは既知の通りである。

（4）第 36 回大会から第 43 回まで 8 回に渡って 「大学体育について」のシンポジウムを行ってい る. 当時の大学改革の流れの中での “一般体育” の改変に対する日本体育学会の対応に呼応するテ ーマであり，本分科会所属会員のニーズに応える シンポジウムであったと思慮できる，とくに， “一般体育”についての現状認識の上に立った改 変を意図した討議内容が多く見られる。「改めて 問われる大学体育の意義」「大学体育の新構想一 21 世紀にむけて一」「生涯スポーツと大学体育」 「必修に値する大学体育とは」「大学体育と新カリ キュラム」「生涯体育・生涯スポーツにおける大 学体育の在り方」等々である，具体的には従来の “必修体育”の見直し・再検討を試み，学生の選 択科目としての体育科目に值する内容をいかに構 築するか等について生涯スポーツや生活体育の実 例を挙げながら真摰な，かつ白熱した討議がなさ れた. 大学教員である多くの本分科会所属会員に は大きな示唆となり, 個々の大学での “一般体育” の在り方に資するところは大であったと思虑でき る.

（5）第 45 回大会から第 48 回大会までの 5 回に 渡って，「コーチングを考える一世界に勝つため に一」とのテーマで行っている。サブテーマの 「世界に勝つために」の討論に見合う競技種目と シンポジストで行われ, 体育方法・スポーツ方法 の核であるコーチング，とりわけ我が国における 
各種目のトップコーチングの実際を明らかにし， 次のステップアップを志向する討議のシンポジウ ムであった，種目としてはサッカー，スキー，ス ケート, テニス, バスケットボール, バレーボー ル，飛び込み，シンクロナイズドスイミングで, 何れも世界選手権大会やオリンピックで好成績を 収めた選手・チームのコーチや監督の発表が続い た。現役監督, 現役コーチの実体験を踏まえた強 化・育成論, 現役選手の立場からのコーチングに ついての意見,諸外国のコーチングと我が国のそ れとの比較の上に立ったトップコーチ実践論，バ ックアップ研究者の立場からのトップコーチ観な ど，多様なシンポジストの発表内容から我が国の トップアスリートのコーチングの実際を知ること ができた。これらの討論・討議内容は各種目のト ップコーチ実践論にとどまらず，他種目のトップ コーチへの転用，あるいは技能レベルに応じたコ ーチングへの活用もでき得る有意義なシンポジウ ムであったと思慮できる.

（6）第 49 回大会では「長野パラリンピックを 考える」というテーマで, 本分科会として初めて 外国からシンポジストを招聘した。Robert Steadward 国際パラリンピック委員会委員長（初 代）に「国際パラリンピックの全体像」を示して もらい, 日本パラリンピック技術強化委員長に 「長野パラリンピックを終えて」，金メダリストに 「長野パラリンピックへの道のり」というテーマ でそれぞれ発表してもらうことができた。今なお よく知られていない部分のあるパラリンピックに ついての全容，コーチング，プレイヤーの実体に ついて討論・討議ができ，障害者のスポーツやそ の指導・コーチングについて目を開くことができ た有意なシンポジウムであった。（なお， R. Steadward 会長から「冬季パラリンピック一その 成果と課題をめぐって一」と題してのキーノート レクチャーも聴くことができた)。

（7）第 50 回大会は記念大会であり，体育・ス ポーツに関わる独立関連学会との共催的学会であ ったので, 本分科会独自のシンポジウムは行わず, 日本スポーツ方法学会として共催シンポジウム 8 セクションにシンポジスト及び司会として会員が
登壇している。

また，第 51 回大会では，合同シンポジウム 「スポーツ科学の 21 世紀への提言一シドニーオリ ンピックに学ぶー」のシンポジストとして「アト ランタからシドニーへ, そしてアテネに问けて (体操競技) 一日本男子体操，世界への再挑戦一」 のテーマで登壇している. アテネオリンピックで の男子国体競技での金メダル獲得は鋭意，選手強 化に力を尽くして来た体操協会の多くのコーチの 努力の集積の成果と考えられる. 種目特性に応じ たトッププレイヤーが各自のパフォーマンスを最 大限に発揮するにはトップコーチのコーチングが 不可欠であり, 体育方法・スポーツ方法学のコー チングの重要性が如実に実証されたと言えよう。

（8）第 52 回大会では「競技力向上を目指す女 性スポーツのコーチング」のテーマで行われてい る. 近年とみに女性選手の国際大会での好成績が 各競技種目で見られるようになったのをうけての テーマ設定であった。「女子柔道選手を対象とし て」「ソフトボール競技のシドニー五輪までの選 手強化と今後に向けて」「シンクロナイズドスイ ミングの競技力向上を目指す女子選手のコーチン グ」と題する 3 競技種目の女子の日本代表選手 . 代表チームのトップコーチングの実際を踏まえて の討論・討議であった。種目特性に応じた女性特 有の身体的・精神的・社会的な資質をいかに技術 向上に活用できるか等を探りながらのトップコー チングの実践の発表内容には多くの示唆を得るこ とができ, 時宜にかなったシンポジウムであった。

（9）第53回大会では「21 世紀の日本サッカ ー・世界のサッカーー2002 FIFA ワールドカッ プを終えて一」のテーマで, 日韓共催の FIFA ワ ールドカップでの日本代表チームの活躍もあり， 社会現象としても稀に見るスポーッ（サッカー） への国民的関心事となったことを受けてのシンポ ジウムであった。Jリーグの技術担当理事，サッ カージャーナリスト, 順天堂大学客員教授の三シ ンポジストにより，我が国のサッカーの来し方と 現状，世界のサッカーの動向と日本サッカーの目 指すものとその課題等について，一過性のブーム に終わることなく世界のトップレベルに伍してい 
く施策の提言にまで及ぶ討論・討議であった。

（10）第 54 回・55回大会では「日本水泳 アジ アからアテネオリンピック〜世界の頂点へ〜」(I) （II）のテーマで行われた. 北島選手のコーチン グスタッフのそれぞれの立場での実際の具体的な 分担・協力内容とその成果をコーディネーターが 質問ふうに尋ねて，興味深いコメントを引き出す 形式で進められた。一方的な発表だけでなく，次 から次への質問と返ってくるコメントによってト ップコーチングの真髄に触れることができたと思 う. 北島選手の世界新記録樹立に向けてのコーチ ングの全容，アテネオリンピックでの金メダルに 向けたコーチングの極限まで待つ決断のしかた等 を軸に討議された。専任コーチの苦悩・呻吟・決 断, 強化サポートスタッフチームのデータ処理 (泳法・記録分析)，トレーナーチェック（指压・ 針尒), メディカルチェック (生理学的諸分析等) の結果のコーチへの報告・戦略の決定とその対応 等を具体的に知り得た有意義なシンポジウムであ った．結果を出したトッププレイヤーをサポート したトップコーチ・スタッフの報告・発表には， 他からは得ることのできないコーチングの実際に 当っての濃密かつ種々多々の示唆が得られた本分 科会にふさわしいシンポジウムであった。

\section{V 日本体育学会大会における キーノートレクチャーについて}

体育方法専門分科会のキーノートレクチャー は, 以下の7学会大会で行われた。

第 40 回学会大会

「体育方法における研究成果の総括」

第 41 回学会大会

「体育・スポーツ方法に関する基本的諸問題」

第 42 回学会大会

「体育・スポーツ方法と人間形成」

第 43 回学会大会

「体育スポーツ方法と健康・体力」

第 48 回学会大会

「人間の生活・生存と生涯体育・スポーツ研究」 第 49 回学会大会
「冬季パラリンピックーその過去・現在・未来 -」

第 53 回学会大会

「日本のサッカーの来し方・行方」

第 40 回学会大会では本分科会が創立されて 20 年の節目にあたり, 本分科会としての研究成果を 総括し, 今後の研究の方向性等についての討論が なされている．第 41 回・第 42 回・第 43 回・第 48 回の 4 回の学会大会では本分科会の「体育方法」 について体育あるいはスポーツ界における方法 （学習，トレーニング，コーチング）を如何に把 え，実践すべきかを人間形成，健康と体力，生 活・生存としての生涯体育・スポーツ等と関連づ けて討論し, 体育方法の方向性についての示唆を 得た。さらに，第 49 回・第 53 回学会大会ではシ ンポジウムと関連させた内容であった。第 49 回 大会のシンポジウムは「長野パラリンピックを考 える—その成果と課題」であった。そこで，パ ラリンピックについて R. Steadward 国際パラリ ンピック委員会委員長のキーノートレクチャーで 理解を梁め, 長野オリンピックについてのシンポ ジウムの討論に結びつけて行われた。その意図は 十分に果せたキーノートレクチャーであった。第 53 回のキーノートレクチャーもシンポジウムの テーマ「21 世紀の日本のサッカー・世界のサッ カーー2002FIFA ワールドカップを終えて一」と リンクした内容であり，「日本のサッカーの来し 方・行方」というテーマであった。ワールドカッ プの興奮・熱気をいかに持続し，世界に伍してい くべきかをめぐる論述であった。

\section{VI 月例研究発表会}

本分科会所属会員により多くの研究発表の場を 提供することと，研究活動を促すことを目的に 「月例研究発表会」を現在まで続けてきている. この呼称は“月例” となっているが，実際は年 4 回の開催である。（諸事情により，年度によって は 5 回あるいは 3 回のときもあった.）発表内容 は体育方法総論, 体育方法論, 運動方法論等の広 範囲にわたり，運動・スポーツ種目の技術に関す 
る発表が多かった。ときには特定のテーマを選定 したり，運動・スポーツ種目を特定したりしての 発表を依頼することもあった。

本研究発表会の 1 回における発表演題数はその ときどきの申し込み数で異なり，一定ではない。 ほぼ $2-3$ 題のときが多く, 4 題のときもあった. また，テーマに沿った総論的な発表を初めに聞い てから 2-3の「課題研究」（指定テーマ）の発 表を行うこともあった。年度ごとの月例研究発表 会の演題数は 12 題前後である.

また，本研究発表会は長く東京中心に首都圈で 開催されて来た。しかし，全国の本分科会所属会 員の研究活動の活性化をはかり，本研究発表会へ のより積極的な参加を促すべく，年に 1 回は首都 圈以外での開催を 1998 年から実施してきている. これまでに北海道，大阪，鹿児島，名古屋，金沢 等で開催し，初期の目的は達成している．開催担 当会員にはご苦労をかける面もあるが，首都圈以 外での本研究発表会は今後も継続していくべきで あろう。

\section{VII「体育方法専門分科会会報」など}

本分科会発足当初より年度ごとに『体育方法専 門分科会会報』を刊行し，全所属会員に配布して きた。内容は分科会の前年度の決算を含む事業報 告と月例研究発表会での発表抄録を収めている. 以下，その内容を略記しておく.

\section{1. 世話人会について}

年間 4-5 回開催している。学会大会における 一般発表形式の検討，シンポジウムのテーマ決定 やシンポジストの選定，月例研究発表会の立案・ 実施案の検討, 次年度の事業計画の審議, 予算・ 決算の審議，分科会会報についての検討等が主な 議事内容となっている．また，本分科会の活動の 現状を踏まえ，今後の分科会としての日本体育学 会内での研究の方向性や分科会所属会員のニーズ にいかに答えていくべきか等についての討議も行 ってきた。

\section{2. 月例研究発表会の発表論文の掲載}

本分科会所属会員の月例研究発表会での口頭発 表を何らかの形でペーパー化できないかという要 望を受けて，上記した年度ごとの『会報』に載せ ることになった。 月例研究発表会で発表された内 容を論文にまとめたものを 10 編前後ずつ載せて きた。なお，1996年からは『体育方法研究報告』 と改称し, 従来の『会報』に収めてきた内容も含 めた研究誌の一つとして刊行している.

\section{おわりに}

以上，粗雑ではあるが日本体育学会体育方法専 門分科会の“足跡”を振り返ってみた。とくに本 分科会所属会員各位には〈指導に関する研究領域〉 として出発した本分科会の「原点」をいま一度ご 確認いただき，各位の今後のご研究の「礎」にし ていただければ幸甚である。

さて，周知のように，カイヨワ (Caillois，R.) は『プレイ』する人が求める楽しさの質の違いに より，『プレイ』をアゴン，アレア，ミミクリー， イリンクスの四つに分類した。これを本分科会が 主要研究対象とする体育・スポーツの“実践現場” に当てはめてみると，【アゴン：競争】の要素が 最も濃い。それはアゴンが1）相手に勝利する, 2）記録更新やフォームの改良，3）一度もできな かった課題ができる一という楽しさを包含してい るからである（松田・宇土，1988）。この3 点は 本稿で検証したように，いわばScienceの範疇で かなり解き明かすことが可能となった.ところが， 今日なお “勝敗は時の運”と喻えられるように， 体育・スポーツの“実践現場”では【アレア：運】 の要素も依然として看過できない。言うならば， Science とは対極的位置づけとなるIntangible の 範疇である。『日本体育学会案内』によると，本 分科会は 'Sports Coaching Methods' と英訳さ れている。つまり，本分科会の研究分野において はScience と Intangible が混在していることにな る。まさに「コーチングはScienceでもあり， Artでもある」といわれる所以であろう。本分科 会に扮ける『研究』ではこのようなことにも留意 
しておきたい。

ところで，伝えられるところによると，日本学 術会議の機構改革が行われることに伴い, 我々の 体育・スポーツ分野に関わる研究推進・統括組織 とでも言える日本体育学会はもとより, 関連独立 専門学会としての日本スポーツ方法学会も少なか らず諸影響を受けるのは必至ではないかと推測さ れる，そのような状況に摇るぎなき対応をしてい くためには “同根同種”である本分科会と日本ス ポーツ方法学会のこれまで以上のリンケージが不 可欠ではないかと思われる。このことも本分科会 所属会員各位にご一考いただければと願ってい る。

なお，本稿の作成にあたっては，本分科会世話 人会・水谷豊会員および城後豊会員に資料収集等
でご協力をいただいた。ここに記してお礼申し上 げる。

\section{文献}

笠井恵雄（1973）体育方法学研究の動向. 体育の科 学, $23: 508-511$.

笠井恵雄（1975）体育方法専門分科会のめざすもの.

体育の科学, $25 ： 834-837$.

笠井恵雄（1977）体育方法学研究の経過と今後の課

題. 体育の科学, $27: 312-315$.

松田岩男 - 宇土正彦編（1988）学校体育用語事典.

大修館書店：東京, p. 300 .

日本体育学会大会号（第 22 回大会一第 55 回大会）

$\left(\begin{array}{l}\text { 平成 } 16 \text { 年 } 11 \text { 月 } 19 \text { 日受付 } \\ \text { 平成 } 17 \text { 年 } 1 \text { 月 } 8 \text { 日受理 }\end{array}\right)$ 